\title{
Review \\ Nutritional, Medicinal, and Cosmetic Value of Bioactive Compounds in Button Mushroom (Agaricus bisporus): A Review
}

\author{
Muhammad Usman ${ }^{1}$, Ghulam Murtaza ${ }^{2}$ iD and Allah Ditta ${ }^{3,4, *(\mathbb{D})}$ \\ 1 Department of Botany, Government College University Lahore, Lahore 54000, Pakistan; \\ usmanphytologist@gmail.com \\ 2 Faculty of Environmental Science and Engineering, Kunming University of Science and Technology, \\ Kunming 650500, China; murtazabotanist@gmail.com \\ 3 Department of Environmental Sciences, Shaheed Benazir Bhutto University Sheringal, Upper Dir, \\ Khyber Pakhtunkhwa 18000, Pakistan \\ 4 School of Biological Sciences, The University of Western Australia, 35 Stirling Highway, \\ Perth, WA 6009, Australia \\ * Correspondence: ad_abs@yahoo.com or allah.ditta@sbbu.edu.pk
}

Citation: Usman, M.; Murtaza, G.; Ditta, A. Nutritional, Medicinal, and Cosmetic Value of Bioactive Compounds in Button Mushroom (Agaricus bisporus): A Review. Appl. Sci. 2021, 11, 5943. https:// doi.org/10.3390/app11135943

Academic Editor:

Panagiota Diamantopoulou

Received: 31 May 2021

Accepted: 23 June 2021

Published: 26 June 2021

Publisher's Note: MDPI stays neutral with regard to jurisdictional claims in published maps and institutional affiliations.

Copyright: (c) 2021 by the authors. Licensee MDPI, Basel, Switzerland. This article is an open access article distributed under the terms and conditions of the Creative Commons Attribution (CC BY) license (https:/ / creativecommons.org/licenses/by/ $4.0 /)$.

\begin{abstract}
Fungi are vital to numerous industrial and household processes, especially producing cheeses, beer, wine, and bread, and they are accountable for breaking down organic matter. The remarkable medicinal and nutritional values of the mushrooms have increased their consumption. Agaricus bisporus belongs to the Agaricaceae family, and it is a top-ranked cultivated mushroom that is well known for its edibility. A. bisporus is rich in nutrients such as carbohydrates, amino acids, fats, and minerals and has potential anticancer, antioxidant, anti-obesity, and anti-inflammation properties. The bioactive compounds extracted from this mushroom can be used for the treatment of several common human diseases including cancer, bacterial and fungal infections, diabetes, heart disorder, and skin problems. A. bisporus has opened new horizons for the world to explore mushrooms as far as their culinary and medicinal values are concerned. In recent years, tyrosinase and ergothioneine have been extracted from this mushroom, which has made this mushroom worth considering more for nutritional and medicinal purposes. To emphasize various aspects of $A$. bisporus, a comprehensive review highlighting the nutritional, medicinal, and cosmetic values and finding out the research gaps is presented. In this way, it would be possible to improve the quality and quantity of bioactive compounds in A. bisporus, ultimately contributing to the discovery of new drugs and the responsible mechanisms. In the present review, we summarize the latest advancements regarding the nutritional, pharmaceutical, and cosmetic properties of $A$. bisporus. Moreover, research gaps with future research directions are also discussed.
\end{abstract}

Keywords: Agaricus bisporus; culinary; bioactive compounds; tyrosinase; ergothioneine

\section{Introduction}

With an increase in the world population, interest in the cultivation and subsequent consumption of mushrooms as a food source has increased. Since 1990, the world started focusing on the mushroom industry, and it resulted in a rapid increase in its production [1,2]. Mushrooms have become one of the most important sources of functional food and medicines in recent years [3,4]. The demand for edible mushrooms has increased due to their taste, flavor, and nutrient content $[5,6]$. Mushrooms are better alternatives to animal proteins and other animal products, and this fact has been supported through various studies conducted in the past [5,7-9]. Several forms of vitamins in mushrooms are responsible for improving health by decreasing the risk of various diseases in humans [10].

Agaricus is one of the largest genera of macrofungi, with several edible species that have medicinal and high nutritional values [11]. Agaricus bisporus (J. E. Lange) Imbach, a 
member of the Agaricaceae family, ranks at the top among cultivated mushrooms, and is well known for its edibility. It is considered as one of the most important mushrooms based on its culinary and medicinal values [12]. Production and consumption of this mushroom have been consistently increasing for the last six to seven decades. China ranks at the top with the highest production of $A$. bisporus. It exports $A$. bisporus mainly to Russia, Japan, Vietnam, Korea, and Thailand and in low amounts to Australia, as well as several European and African countries [13].

Button mushroom is another name of $A$. bisporus and it is a valuable source of food and several important bioactive compounds [14]. Several important bioactive compounds have been isolated from $A$. bisporus during the past few years [15]. The bioactive compounds with nutritional value in $A$. bisporus contribute to human health. Several studies have also reported the role of this mushroom in the cosmetics industry as it contains certain constituents that enhance facial beauty by controlling various skin problems $[8,16,17]$. A summary of the nutritional, medicinal, and cosmetic value of $A$. bisporus is given in Figure 1.

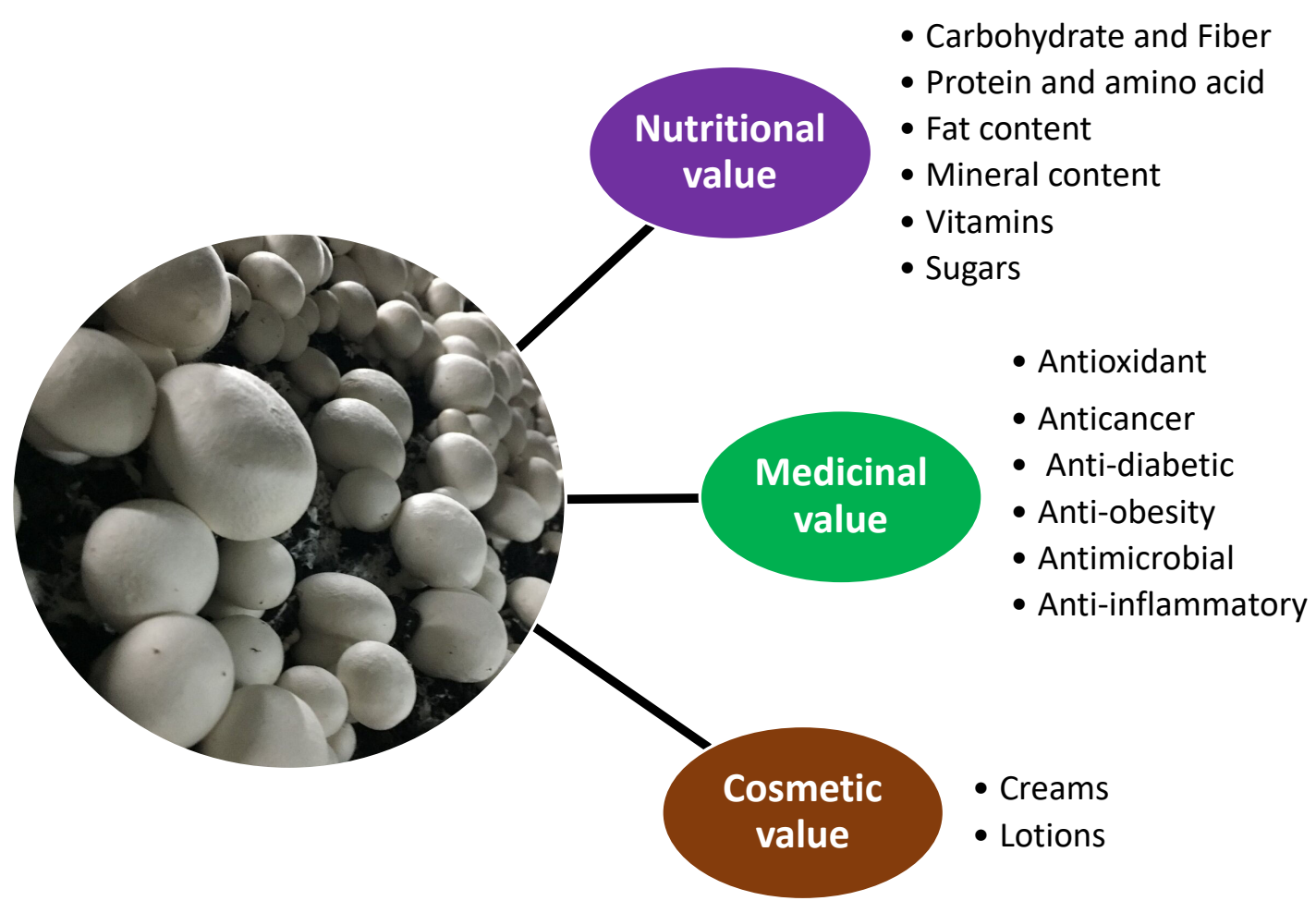

Figure 1. A summary of nutritional, medicinal, and cosmetic value of Agaricus bisporus.

From Figure 1, it is clear that $A$. bisporus has great potential from nutritional, medicinal, and cosmetic aspects. There is a need to emphasize these aspects, and this could only be possible through a comprehensive review of multidimensional aspects of $A$. bisporus and finding out the research gaps. In this way, the quality and quantity of bioactive compounds in A. bisporus would be enhanced, ultimately contributing towards nutritional, medicinal, and cosmetic aspects. The new research work may also result in the discovery of new drugs from the bioactive compounds in A. bisporus by employing latest state-of-the-art technologies. Based on these hypotheses, the present review aims to have a comprehensive view of the nutritional, medicinal, and cosmetic value of bioactive compounds in Agaricus bisporus.

\section{Nutritional Value}

Various studies have been conducted to evaluate the nutritional value of $A$. bisporus $[8,18-25]$. 
Tables 1 and 2 represent the various nutritional components of $A$. bisporus found in different studies. A. bisporus is relatively rich in carbohydrates, proteins, and fats as compared to some other widely consumed species [26]. According to El Sebaaly et al. [27], mushrooms exhibit different nutritional value when grown on different substrates.

Table 1. Nutritional status of $A$. bisporus.

\begin{tabular}{cc}
\hline \multicolumn{1}{c}{ Raw Nutritional Value/100 g } \\
\hline Energy & $94 \mathrm{KJ}(22 \mathrm{kcal})$ \\
Water & $92.43 \mathrm{~g}$ \\
Fats & $0.34 \mathrm{~g}$ \\
Proteins & $3.09 \mathrm{~g}$ \\
Carbohydrates & $3.26 \mathrm{~g}$ \\
Dietary fibers & $1 \mathrm{~g}$ \\
Sugar & $1.65 \mathrm{~g}$ \\
Iron & $0.50 \mathrm{mg}$ \\
Vitamin C & $2.1 \mathrm{mg}$ \\
Niacin (Vit B3) & $3.607 \mathrm{mg}$ \\
Riboflavin (Vit B2) & $0.402 \mathrm{mg}$ \\
Pantothenic acid (B5) & $1.497 \mathrm{mg}$ \\
\hline
\end{tabular}

Source: USDA Nutrient database.

Table 2. Nutritional components present in the basidiocarp of A. bisporus.

\begin{tabular}{|c|c|c|c|c|}
\hline Nutritional Group & Components & Amount & Unit & References \\
\hline \multirow{17}{*}{ Proteins (amino acids) } & Alanine & 5.8 & & \multirow{17}{*}[28-30]{} \\
\hline & Cysteine & 1.1 & $\mathrm{~g} 100 \mathrm{~g}^{-1}$ total protein & \\
\hline & Proline & 6.1 & in FW & \\
\hline & Tyrosine & 4.2 & & \\
\hline & Methionine & 0.8 & \multirow{13}{*}{$\mathrm{mg} \mathrm{g}^{-1} \mathrm{DW}$} & \\
\hline & Threonine & 1.3 & & \\
\hline & Asparagine acid & 3.4 & & \\
\hline & Serine & 3.1 & & \\
\hline & Histidine & 14.1 & & \\
\hline & Leucine & 0.8 & & \\
\hline & Arginine & 2.2 & & \\
\hline & Lysine & 3.5 & & \\
\hline & Phenylalanine & 2.1 & & \\
\hline & Glycine & 2.0 & & \\
\hline & Valine & 2.3 & & \\
\hline & Isoleucine & 1.0 & & \\
\hline & Total amount of amino acids & 44.2 & & \\
\hline \multirow{15}{*}{ Lipids (fatty acids) } & Palmitic acid & 13.35 & \multirow{14}{*}{$\mathrm{mg} 100 \mathrm{~g}^{-1} \mathrm{DW}$} & \multirow{15}{*}{ [31] } \\
\hline & Palmitoleic acid & 4.84 & & \\
\hline & Caprylic acid & 1.08 & & \\
\hline & Caprinic acid & 0.85 & & \\
\hline & Oleic acid & 6.07 & & \\
\hline & Linoleic acid & 67.29 & & \\
\hline & Linolenic acid & 1.52 & & \\
\hline & Laurnic acid & 0.11 & & \\
\hline & Myristic acid & 0.94 & & \\
\hline & Stearic acid & 3.72 & & \\
\hline & Arachidic acid & 0.92 & & \\
\hline & Pentadecanoic acid & 0.23 & & \\
\hline & Total unsaturated fatty acids & 79.72 & & \\
\hline & Total saturated fatty acids & 20.28 & & \\
\hline & Total lipids & 2.7 & $\% \mathrm{DW}$ & \\
\hline
\end{tabular}


Table 2. Cont.

\begin{tabular}{|c|c|c|c|c|}
\hline Nutritional Group & Components & Amount & Unit & References \\
\hline \multirow{4}{*}{ Carbohydrates } & Total sugars & 4.50 & & \multirow{4}{*}[30,32]{} \\
\hline & Fructose & 2.62 & g $100 \mathrm{~g}^{-1} \mathrm{FW}$ & \\
\hline & Mannitol & 23.62 & & \\
\hline & Trehalose & $1-3$ & $\%$ DW & \\
\hline \multirow{6}{*}{ Indol compounds } & Indoloacetic acid & 0.19 & \multirow{6}{*}{$\operatorname{mg} 100 \mathrm{~g}^{-1} \mathrm{DW}$} & \multirow{6}{*}[8,22]{} \\
\hline & Tryptamin & 0.06 & & \\
\hline & Kynurenic acid & 6.21 & & \\
\hline & Melatonin & 0.11 & & \\
\hline & Serotonin & 5.21 & & \\
\hline & L-Tryptophan & 0.39 & & \\
\hline \multirow{11}{*}{ Vitamins } & Niacin & 42.0 & \multirow{8}{*}{$\operatorname{mg} 100 \mathrm{~g}^{-1} \mathrm{DW}$} & \multirow{11}{*}[28,33,34]{} \\
\hline & Vitamin B1 & 0.6 & & \\
\hline & Vitamin B2 & 5.1 & & \\
\hline & Vitamin B3 & 43.0 & & \\
\hline & Vitamin C & 17.0 & & \\
\hline & $\gamma$-Tocopherol & $2-3$ & & \\
\hline & $\alpha$-Tocopherol & $1-4$ & & \\
\hline & $\delta$-Tocopherol & 1.0 & & \\
\hline & Folic acid & 450 & & \\
\hline & Vitamin B12 & 0.8 & $\mu \mathrm{g} 100 \mathrm{~g}^{-1}$ & \\
\hline & Vitamin D & 3.0 & & \\
\hline \multirow{10}{*}{ Phenolic compounds } & Ferulic acid & 42.83 & \multirow{10}{*}{$\mathrm{mg} \mathrm{kg}^{-1} \mathrm{DW}$} & \multirow{10}{*}[23,30,35,36]{} \\
\hline & Gallic acid & 280.45 & & \\
\hline & Cinnamic acid & 0.38 & & \\
\hline & Myricetin & 2729.46 & & \\
\hline & Caffeic acid & 392.51 & & \\
\hline & Catechins & 56.74 & & \\
\hline & Procatechuic acid & 83.26 & & \\
\hline & $p$-Coumaric acid & 2.31 & & \\
\hline & Total phenols & $277-687$ & & \\
\hline & Free phenols & $176-487$ & & \\
\hline \multirow{4}{*}{ Sterols } & Ergosta-7, 22-deiniol & 2.45 & \multirow{4}{*}{$\mathrm{mg} 100 \mathrm{~g}^{-1} \mathrm{DW}$} & \multirow{4}{*}[37,38]{} \\
\hline & Ergosterol & 186.1 & & \\
\hline & Ergosta-7-enol & 1.73 & & \\
\hline & Ergosta-5,7-deiniol & 6.05 & & \\
\hline
\end{tabular}

Note: $\mathrm{mg}$ = Milligram; kg = Kilogram; g = Gram; DW = Dry weight; FW = Fresh weight.

\subsection{Proteins and Amino Acids}

Mushrooms contain relatively high protein contents compared to animal products, but usually rank below animal meats [8]. However, it is reported that pre- and post-harvest conditions affect the nutritional and chemical composition of mushrooms. Moreover, different mushrooms' developmental stages exhibit different amounts of protein and amino acid contents $[20,26,39,40]$. A. bisporus is rich in different forms of amino acid (Figure 2).

The amino acids continuously assimilate to produce urea, which contributes to the overall mushroom's total nitrogen contents [41]. Post-harvested mushrooms were reported to shown protease activity [42]. Mushrooms growing on different substrates display variable protein contents as reported by different researchers around the world. Braaksma and Schaap [43] reported that major forms of amino acids in A. bisporus include aspartic acid, serine, glycine, threonine, glutamine, valine, cysteine, alanine, leucine, isoleucine, lysine, histidine, proline, arginine, tyrosine, and norleucine. Moreover, crude protein contents in A. bisporus ranged from $19-38 \%$ on a dry weight basis. Several studies in the past have focused on determining the overall protein and amino acid content of A. bisporus. According to Sadiq et al. [44], 11.01\% protein contents were found in A. bisporus. Muszynska et al. [22] recorded the presence of 
proteins up to $11.01 \%$ in $A$. bisporus. However, Mohiuddin et al. [45] found that A. bisporus contained 17.7-24.7\% protein contents while Ahlavat et al. [25] reported the presence of $29.1 \%$ protein contents in $A$. bisporus. These results indicate that the protein contents vary in A. bisporus based on the usage of different growth substrates.

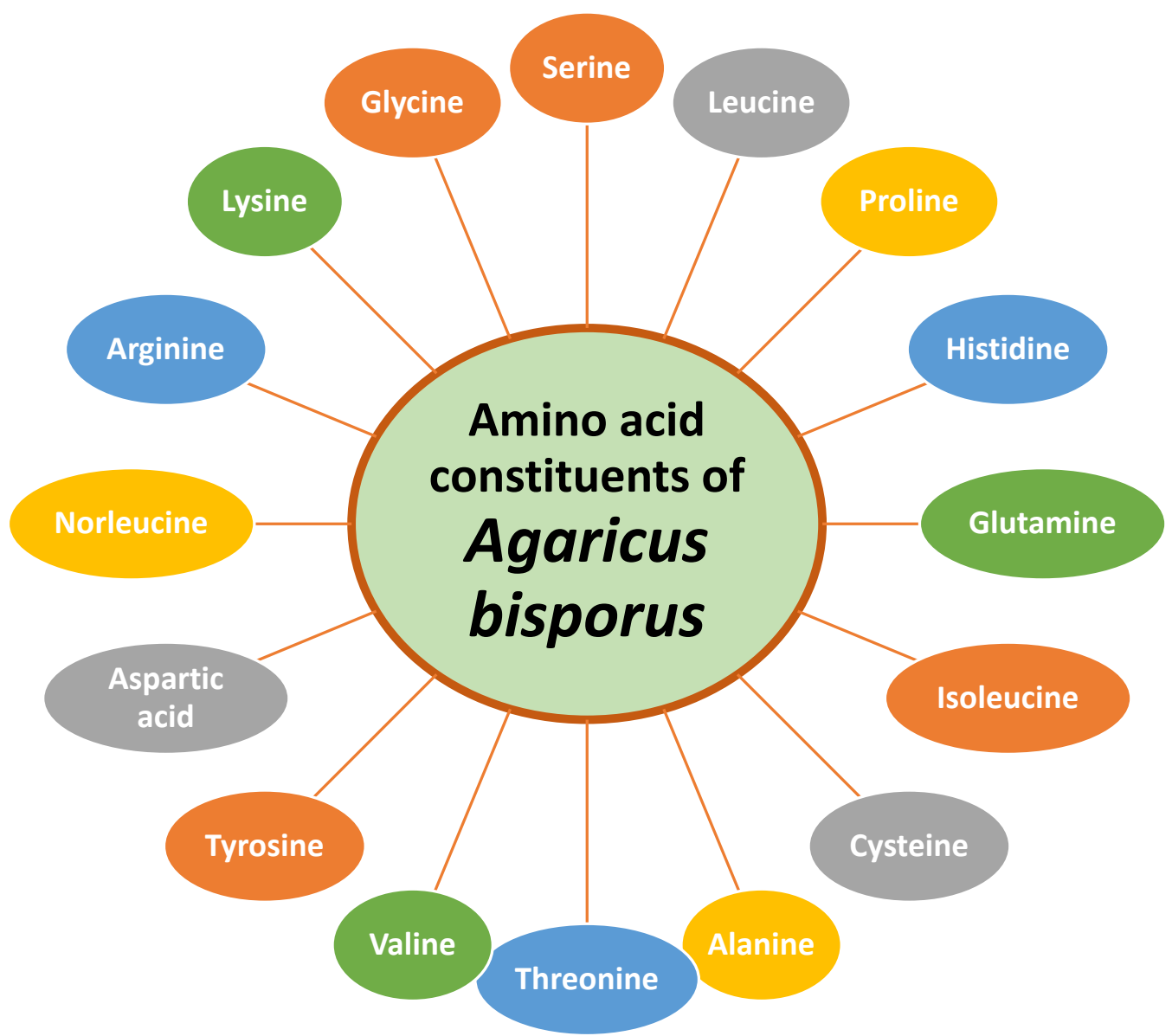

Figure 2. Amino acid constituents in Agaricus bisporus [43].

Recently, a novel class of specific ribonucleases, known as "ribotoxin-like proteins," have been discovered [46,47]. It has been found that ribotoxins are widely distributed among various species of mushrooms. Citores et al. [46] isolated a ribotoxin, i.e., "Ageritin," from Agrocybe aegerita and found that it possessed multiple biological activities, i.e., antibacterial, antiviral, endonuclease, nuclease, and cytotoxic activities, which could be employed in plants through transgenic techniques to enhance resistance against viruses, bacteria, and fungi.

\subsection{Lipids}

Crude fats are present only in small amounts while a considerable amount of essential fatty acids like linoleic acid are present in A. bisporus. As compared to A. bisporus cultivated strains, wild Agaricus sp. contains relatively higher amounts of polyunsaturated fatty acids and a lower concentration of monounsaturated fatty acids [19]. According to Baars et al. [48], the total fatty acid contents ranged from $180-5818 \mathrm{mg} \mathrm{kg}^{-1} \mathrm{DW}$ and linoleic acid represented almost $90 \%$ of the fat contents present in A. bisporus.

The fatty acid constituents in $A$. bisporus were stearic acid, palmitic, linoleic, caprylic, oleic, erucic, and eicosanoic acid, which accounted for about $44.19 \%$ of the total extracted fatty acid [44]. Two fatty acids, i.e., palmitic (12.67-14.71\%) and linoleic acids (61.82$67.29 \%$ ), are the main fatty acids in A. bisporus among the detected 13 fatty acids [31]. However, Shao et al. [21] reported palmitic, linoleic, and stearic acids as the major fatty 
acids found in A. bisporus. Hossain et al. [49] investigated the principal fatty acids in two important edible mushrooms, i.e., Pleurotus ostreatus and Ganoderma lucidum (Curtis) P. Karst., and found that linoleic acid was five-fold and twenty-fold more than the total fatty acids measured, respectively.

\subsection{Carbohydrate and Fibers}

Undoubtedly, carbohydrates are a basic component of human food, and mushrooms are a significant source of both forms of carbohydrates, i.e., digestible and non-digestible. Glucose and mannitol are the two important digestible carbohydrates but are present in low quantities (not more than $1 \%$ of the dry weight) in A. bisporus. Moreover, glycogen is another digestible carbohydrate, which ranges from 5 to $10 \%$ of the dry weight in A. bisporus. Trehalose, mannans, and $\beta$-glucan are non-digestible carbohydrates, which constitute a major portion of the carbohydrate contents in A. bisporus [8,50]. Reis et al. [23] examined the carbohydrate contents in A. bisporus and found that trehalose and mannitol were the two most abundant sugars. Mannitol represents the most plentiful sugar in A. bisporus [48] Mannitol was the principal form of soluble sugar in fresh fruiting bodies of this species, followed by glucose ranging from $17.6-28.1 \mathrm{mg} \mathrm{g}^{-1}$ in several phases of its maturity [51,52].

Cheung [50] stated that the dietary fibers included chitin, which is predominated in the fungal cell wall. Mannans, hemicelluloses, and glucans are also present in significant amounts in the fungal cell wall, which, as a result, contribute to the medicinal properties of the mushrooms. Atila et al. [53] determined the chitin contents in A. bisporus as $9.60 \mathrm{~g} 100 \mathrm{~g}^{-1}$ dry matter. Vetter [54] found that the chitin contents were much higher in A. bisporus compared to Lentinula edodes (Berk.) Pegler and P. ostreatus (Jacq. ex Fr.) P.Kumm. It is important to understand that chitin is an insoluble fiber, which promotes immune functioning and improves gut health. Higher chitin contents also contribute towards A. bisporus health. Cherno et al. [55] measured the chitin contents in A. bisporus and concluded that it had approximately two times more chitin contents in comparison to P. ostreatus.

\subsection{Minerals}

A. bisporus is considered an important source of minerals, predominately rich in copper $(\mathrm{Cu})$, cobalt $(\mathrm{Co})$, iron $(\mathrm{Fe})$, selenium $(\mathrm{Se})$, potassium $(\mathrm{K})$, and manganese $(\mathrm{Mn})[20,52]$. The principal mineral constituents of fruiting bodies in mushrooms are phosphorus $(\mathrm{P})$ and potassium $(\mathrm{K})$, followed by calcium $(\mathrm{Ca})$, zinc $(\mathrm{Zn})$, iron $(\mathrm{Fe})$, magnesium $(\mathrm{Mg})$, and sodium (Na). These minerals have been found in the A. bisporus and impart their role in the health benefits of the mushroom [56].

Mohiuddin et al. [45] investigated the mineral contents in A. bisporus growing under different locations. The mineral contents $\left(\mathrm{mg} \mathrm{kg}^{-1}\right)$ ranged in the samples as 37.2-61.9 for sodium (Na), 54.6-163.4 for copper, 56.2-91.1 for magnesium (Mg), 143.6-396 for iron $(\mathrm{Fe})$, and 36.6-58.0 for zinc ( $\mathrm{Zn})$. Caglarırmak [57] also determined different mineral contents in A. bisporus as calcium (534.2-554.8 $\mathrm{mg} \mathrm{kg}^{-1}$ ), potassium (213.3-238.8 $\left.\mathrm{mg} \mathrm{kg}^{-1}\right), \mathrm{Fe}$ (7.4-7.9 mg kg $\left.{ }^{-1}\right), \mathrm{Zn}\left(8.1-8.7 \mathrm{mg} \mathrm{kg}^{-1}\right), \mathrm{Na}\left(2652-2500 \mathrm{mg} \mathrm{kg}^{-1}\right), \mathrm{Mg}\left(88.0-76.3 \mathrm{mg} \mathrm{kg}^{-1}\right)$ and phosphorus (7.4-7.9 $\mathrm{mg} \mathrm{kg}^{-1}$ ). Similarly, Ahlavat et al. [25] calculated the mineral content in the fruiting bodies of $A$. bisporus as $\mathrm{Na}\left(500.8 \mathrm{mg} \mathrm{kg}^{-1}\right)$ and Se $\left(1.34 \mathrm{mg} \mathrm{kg}^{-1}\right)$. Lu and Holmgren [58] stated that $\mathrm{Se}$ in A. bisporus is a crucial micronutrient for animals and humans.

\subsection{Vitamins}

Various studies have confirmed that mushrooms are a valuable source of vitamins. Bernas \& Jaworska [59] stated that the most abundant vitamins in A. bisporus included niacin and riboflavin. Other important vitamins included $\alpha$-tocopherol, ascorbic acid, vitamin B1, and vitamin B3. Caglarırmak [57] stated that the A. bisporus is rich in vitamins such as riboflavin, folic acid, thiamin, and niacin, but poor in vitamin $C$ content. Furlani and Godoy [60] calculated the mean values of vitamins B1 (Thiamin) and B2 (Riboflavin) from a fresh specimen of A. bisporus and found that vitamin B1 and B2 were 0.03 and 
$0.25 \mathrm{mg} 100 \mathrm{~g}^{-1}$, respectively. Moreover, vitamin B2 amounts in A. bisporus, Pleurotus spp,. and L. edodes, except for conserved mushrooms, were greater than that of various vegetables. Ahlavat et al. [25] demonstrated that this species is an ample source of vitamin D (984 IU g $\left.{ }^{-1}\right)$. Simon et al. [61] stated that vitamin D contents vary in wild and cultivated strains of $A$. bisporus. Reis et al. [23] found that the poor contents of vitamin D could be due to the cultivation of species in darkness. Roberts et al. [62] reported that exposure to UV radiation helps to enhance the production of vitamin D. Ergo-sterol is also present in the fungal cell wall and is a precursor of vitamin D2. Shao et al. [21] stated that ergo-sterol content usually correlates with the mushroom's antioxidant activity.

\section{Medicinal Value}

With time, there has been an increased interest in consuming mushrooms to cure or treat many deadly diseases worldwide. A. bisporus is the best example of mushrooms that has great medicinal and nutritional properties. A. bisporus has long been used in traditional therapies in many different states and countries. Various studies have confirmed that bioactive compounds, powder, and even extract from A. bisporus can be used to treat various deadly human diseases. This trend is increasing with every passing day. It has potential anticancer, antioxidant, anti-obesity, and anti-inflammation properties and could be used to treat coronary heart diseases, cancer, diabetes mellitus, disorders related to the immune system, viral, bacterial and fungal infections [30,63]. Hence, the consumption of $A$. bisporus makes the human body more resistant to various diseases as it boosts the immune functioning of the body [64]. However, comparatively few studies have reported the direct treatment trials of mushrooms using humans to confirm the medicinal potential of $A$. bisporus against various diseases [65]. Various studies have confirmed anticancer activity [53,66-69], antioxidant [19,70,71], and anti-diabetic [72-77] properties of A. bisporus. The following sections give a detailed description of each medicinal property of $A$. bisporus. Recently, a novel class of specific ribonucleases, known as "ribotoxin-like proteins", have been discovered [46,47]. It has been found that ribotoxins are widely distributed among various species of mushrooms and are responsible for various biological activities against bacteria, viruses, and fungi.

\subsection{Antioxidant Properties}

A. bisporus exhibits comparatively higher antioxidant potential compared with other important edible mushrooms like P. eryngii (DC.) Quel., Grifola frondosa (Dicks.) Grey, P. ostreatus, and L. edodes [14,53]. Oms-Oliu et al. [70] reported 100.32-100.78 $\mathrm{mg}_{100 \mathrm{~g}^{-1}}$ phenolic content based on the fresh weight in fresh-cut $A$. bisporus. Moreover, ergothioneine contents from brown and white $A$. bisporus ranged from $0.21-45 \mathrm{mg} \mathrm{g}^{-1} \mathrm{DW}$. Liu et al. [71] examined the chief phenolic compounds from ethanolic extract of $A$. bisporus and confirmed the presence of natural antioxidants, such as catechin, ferulic acid, gallic acid, protocatechuic acid, and myricetin. Some other researchers have also confirmed the presence of antioxidants in A. bisporus [53,78-81].

Sarikaya \& Gulcin [82] stated that serotonin is another important biochemical compound that exhibits great antioxidant potential. Because of its antioxidant potential, serotonin extracted from mushrooms have a potential to prevent Alzheimer's disease [83]. Muszynska et al. [22] calculated the serotonin content from fruiting bodies of A. bisporus, which was $5.21 \mathrm{mg} 100 \mathrm{~g}^{-1}$ dry weight. Tocopherol is a class of fat-soluble vitamins and an important antioxidant involved in many body functions. White $A$. bisporus was found rich in $\beta$-tocopherol, i.e., $0.85 \mu \mathrm{g} 100 \mathrm{~g}^{-1}$ fresh weight [23].

\subsection{Anticancer Properties}

Over the last few decades, cancer has remained one of the few life-threatening diseases on Earth. Recent reports have confirmed that the polysaccharides extracted from some mushrooms inhibit cancer cell lines because of their significant anticancer activity [84]. Polysaccharides from A. bisporus have significant action against cancerous cells via en- 
hancing cellular immunity. According to the Canadian Cancer Society, increased use of A. bisporus enhances immune functions as it exhibits effectiveness against some deadly diseases [85]. A. bisporus contains a large amount of several important polysaccharides, which have anti-tumor and strong immune-stimulatory activity in vitro and in vivo [86].

Smiderle et al. [87] reported three principal polysaccharides in A. bisporus, namely galactomannan, $\alpha$-glucan, and $\beta$-glucan, contributing about $55.8 \%$. McCleary and Draga [88] reported that the low $\beta$-contents in this species are beneficial in enhancing mucosal immunity. Jeong et al. [68] stated that a significant dietary fiber level speeds up the secretion of immunoglobulin A.

Jagadish et al. [89] reported that lectins and phenolic compounds in A. bisporus suppress tumorous cells. The study was carried to show the effect of bioactive compounds extracted from A. bisporus on cancer line cells. The results showed that proliferation of HL-60 leukemic cells was inhibited by $A$. bisporus extract as it stimulated programmed cell death [90]. Similarly, A. bisporus extract suppressed the growth of prostate cancer PC3 and DU145 cells of mice [91,92].

A. bisporus extract containing lectins was effective against lung cancer cells by strengthening the cellular mechanism of antioxidant defense and inhibiting the growth of cancerous cells [68]. Arginine from basidiocarp of A. bisporus retards the growth of tumor cells. The study recommended that persons particularly cancer patients should use this particular mushroom regularly as dietary supplements. ABP-1 and ABP-2 are polysaccharide fractions that suppressed the growth of breast cancer cells (MCF-7), but their effect on gastric cancer, prostate cancer, sarcoma, and colorectal carcinoma was not statistically significant $[67,93]$.

Selenium (Se) is an essential trace element for animals, including humans. According to Clark et al. [94], Se contents are found more in mushrooms compared to the fruits and vegetables. The A. bisporus is a valuable source of trace minerals that contributes to its health benefits. Se has a crucial role in the chemoprevention of cancer. Spolar et al. [95] reported that the Se makes the immune system stronger to fight against some deadly diseases including cancer. Rzymski et al. [96] stated that the higher doses of Se significantly alleviate the chances of cancer. Major types of cancer including lung, liver, colon, and prostate can be prevented by the antioxidants present in A. bisporus.

\subsection{Anti-Diabetic Activity}

Various studies have confirmed the anti-diabetic activities of A. bisporus [30,65,73-76, 97-100]. A. bisporus holds significant levels of antioxidants such as vitamin C, D, and B12, as well as polyphenols, folates, and dietary fibers, which have inhibitory effects against diabetes and cardiovascular disorders [75]. Calvo et al. [76] isolated a variety of bioactive compounds from $A$. bisporus that have the potential to defend the body against type 2 diabetes. Ekowati et al. [100] found that $A$. bisporus extract significantly increased insulin production and G6PD activity with a substantial decrease in glucose concentration in the rat's body. Similarly, the use of $A$. bisporus also caused a significant increase in low-density lipoprotein (LDL) levels, cholesterol, and triglyceride. Moreover, a decrease in malondialdehyde level was substantial while superoxide dismutase, catalase, and glutathione peroxidase were significantly increased [100].

The high amount of dietary fibers (about 19\%) and some other valuable carbohydrate constituents in A. bisporus may result in its glucose-lowering effect. The effect of dietary fibers from A. bisporus is similar as observed in other high-valued mushrooms [97,101]. The lectin-like molecules in A. bisporus are responsible for decreasing glucose and increasing insulin contents. A. bisporus is contributing to lower blood glucose levels due to high fiber contents. High fiber contents in A. bisporus act as a barrier against the action of digestive enzymes, which lowers the blood glucose level [73,74].

Propionate, an ester of propionic acid extracted from A. bisporus, contributes to its antidiabetic properties $[102,103]$. Propionate is associated with gluconeogenesis and regulation of serum lipid levels and is reported to lower blood glucose levels. Wong et al. [104] 
investigated the possible mechanisms in lowering the body's blood glucose level using A. bisporus. It was found that fibers in A. bisporus are involved in bacterial fermentation, which contains an ample amount of oligosaccharide and polysaccharide and ultimately results in increased production of short-chain fatty acids in the colon.

Volman et al. [65] demonstrated that the intake of $\alpha$-glucan lowered the lipopolysaccharide production, which resulted in a substantial decrease in glucose concentration. Ekowati et al. [100] reported that terpenoids and flavonoids are secondary compounds that increase SOD activity in rats suffering from diabetes. Huang et al. [98] reported that flavonoids increased the expression levels of endogenous antioxidant genes and consequently increase SOD activity. Terpenoids are involved in the modulation of SOD activity [99]. The high contents of zinc (7.5-15 mg $\left.100 \mathrm{~g}^{-1} \mathrm{DW}\right)$ in the basidiocarp of A. bisporus significantly improve the SOD activity [30].

\subsection{Anti-Obesity Activity}

Hyperlipidemia is a dominant risk factor represented by raised levels of triglyceride or cholesterol. It results in the most serious heart diseases and atherosclerosis in humans [105]. Mushrooms are highly nutritive, exhibiting tremendous amounts of bioactive compounds (alkaloids, flavonoids, polysaccharides, polyphenols, fibers, sterols, and terpenes) that have antioxidant potential with positive effects on numerous cardiac biomarkers in treating obesity and obesity-related cardiovascular illnesses [81]. Lin et al. [106] reported that phytosterols or plant sterols reduce cholesterol absorption. Phytosterols extracted from the A. bisporus reduce LDL cholesterol and plasma cholesterol. Xu et al. [107] stated that A. bisporus also exhibits a substantial amount of lovastatin, which lowers the cholesterol levels in the body to reduce the chances of cardiovascular disorders.

Jeong et al. [75] demonstrated that the consumption of $A$. bisporus basidiocarp regulates anti-cholesterolemic and anti-glycemic responses in rats fed with a high cholesterol diet and rats suffering from type 2 diabetes induced by streptozotocin injection $\left(50 \mathrm{mg} \mathrm{kg}^{-1}\right.$ body weight). The results showed that the A. bisporus has both anti-hypercholesterolemic and anti-glycemic effects in rats. Additionally, it imparted a positive effect on lipid metabolism as well as on liver functioning.

\subsection{Antimicrobial Activity}

A. bisporus contains many bioactive compounds responsible for antimicrobial activities. The use of traditional synthetic medicines in providing relief against plants, animals, and human diseases has not proven quite productive [108]. Research has examined that grampositive bacterial growth and development were greatly inhibited via methanol extract from wild A. bisporus. Methanol extract had little impact on the growth and development of gram-negative bacteria in comparison to gram-positive bacteria [31]. Mycochemical analysis and activities of A. bisporus are presented in Table 3.

Table 3. Mycochemical analysis and activities in Agaricus bisporus.

\begin{tabular}{ccc}
\hline Mycochemicals & Activities & References \\
\hline Alkaloids & Antimicrobial, Anti-inflammatory, Antioxidant & {$[53,109]$} \\
Carbohydrate & Antimicrobial & {$[20,31,53,110,111]$} \\
Phenols and Polyphenols & Antimicrobial, Anti-inflammatory, Antioxidant & {$[53,109,112]$} \\
Protein and Amino acids & Antimicrobial, Anti-inflammatory & {$[113]$} \\
Saponins & Anticancer, Antioxidant & {$[114]$} \\
Tannins & Antimicrobial, Antioxidant & {$[115]$} \\
\hline
\end{tabular}

Shang et al. [116] reported similar findings from the Chinese strain, where A. bisporus extract did not affect gram-negative bacteria. On the other hand, Soltanian et al. [117] examined the effect of crude extract on the growth and development of gram-negative and gram-positive bacteria. In the results, crude extract from both cultivated and wild A. bisporus only showed inhibitory effects on gram-positive bacteria. Contrary to this, there 
are also reports about the repressive effect of $A$. bisporus crude extract on gram-negative bacteria, and the main susceptible species included Listeria monocytogenes, Escherichia coli, Klebsiella pneumonia, and Pseudomonas aeruginosa [118-120].

In the secondary metabolites of $A$. bisporus extract, a few compounds have antimicrobial activity. Only a few studies have been conducted to investigate which particular compound is responsible for antimicrobial activity. However, during the last few years, some valuable findings have been published [121]. The aqueous protein extract from cultivated A. bisporus has shown a significant antibacterial activity, specifically against Staphylococcus aureus [122].

The growth of two bacterial species, namely Escherichia coli and S. aureus, was significantly inhibited via ethanol and cold-water extract from A. bisporus [123]. DelgadoPovedano et al. [124] found that the potential antiviral activity of aqueous enzymatic extracts of $A$. bisporus could prevent $\mathrm{HCV}$ infection due to the antagonistic activity of the extract against $\mathrm{HCV}$ protease.

\subsection{Anti-Inflammatory Properties}

Some studies have confirmed the anti-inflammatory properties of $A$. bisporus $[15,93,125$, 126]. Mannogalactan, fucomannogalactan, and fucogalactan are the polysaccharides isolated from A. bisporus that exhibit analgesic and anti-inflammatory properties [126]. Heterogalactan is another polysaccharide extracted from this species that can combat sepsis in mice [125]. Golak-Siwulska et al. [93] stated that sepsis is a very grievous medical problem and one of the principal causes of death in intensive care units throughout the world, and heterogalactan from the A. bisporus can be helpful in these cases. Ruthes et al. [15] demonstrated that A. bisporus could fight sepsis as it exhibits a strong anti-inflammatory effect.

\section{Cosmetic Value}

The mushrooms have been mainly investigated for their medicinal and nutritional values [127]. However, little work has been done in exploring the biotechnological potential of mushroom extract for the formulation of plenty of cosmetic products $[128,129]$. It has been found that skin whitening could be achieved by inhibiting the tyrosinase enzyme activity [130-132]. The cosmetic industry has been working continuously to isolate some important ingredients from mushrooms and confirm their aesthetic values and their subsequent use in cosmetic products such as lotions and creams [133].

Intrinsic or natural mechanisms lead to skin aging. This process considerably affects the skin and various other body parts through hormonal alterations happening with age and exposure to ultraviolet radiations, which result in the generation of reactive oxygen species (ROS), causing oxidative stress [134]. Activator factor-1 (AP-1) is one important transcription factor accelerated by ROS and is known to enhance elastin and carries out the breakdown of collagen by up-regulation of Matric Metallo-Proteinase [135]. In the modern world, people are more interested in using natural compounds for skincare. In addition, the demand for natural compounds is increasing due to their defensive and protective role against free radical generation and reduction in oxidative enzyme production. Tyrosinase enzyme extracted from the A. bisporus has been found effective against inflammation and inflammatory diseases [136].

Ethanolic extract from $A$. bisporus exhibits strong antioxidant properties, thereby playing an important role in curing skin aging. Extracts from A. bisporus possess antibacterial activity against harmful microorganisms including methicillin-resistant and methicillinsusceptible Staphylococcus aureus. These bacteria are known to colonize the skin during injury and inflammation. The base cosmetic cream prepared from mushroom extracts displayed anti-inflammatory and antioxidant potential against the production of nitric oxide and melanin by suppressing the tyrosinase activity [137]. Cosmetic formulations comprising mushroom extracts suppress the growth of bacterial strains, which cause damage to the skin. Certain bioactive compounds in the base cream extracted from mush- 
rooms enhance beauty and play an important role against inflammation, skin aging, and hyper-pigmentation [133].

The base cream prepared from the $A$. bisporus extract displayed a significant antioxidant potential and antibacterial action against some bacterial strains [120,129]. The extract from this species containing a bioactive compound (2-Amino-3H-phenoxazin-3-one) utilized in specific concentrations, e.g., at $0.5,1$, and $2 \mu \mathrm{M}$, inhibited the production of melanin by 80 , 54.1, and 39.4\%, respectively [137]. Phenolic compounds possess antibacterial activity that usually disrupts the bacterial membranes and damages DNA [138]. Alves et al. [139] found that the $A$. bisporus extract showed a non-significant resistance against two gram-negative bacteria, i.e., E. coli and P. aeruginosa.

A. bisporus is an edible mushroom that often accumulates Se as a trace mineral in their fruiting bodies $[140,141]$. Shampoos can be formulated using $A$. bisporus extract in resolving hair problems like dandruff, oily hair, and hair loss. It can also be used for cleansing the hair and scalp for better growth of the hairs [142]. A. bisporus contains vitamin D and several minerals including copper, iron, and Se, which play an important role in making hairs healthy and strong, thereby preventing hair loss and dandruff [127]. The trend of using mushrooms in the cosmetic industry should increase with time.

\section{Conclusions and Future Perspectives}

Agaricus bisporus is not only a valuable source of food but also exhibits medicinal and cosmetic values. During the last two decades, interest in the consumption of $A$. bisporus has increased, predominantly in developed and developing countries as supplements to healthy food. Many studies have confirmed that the bioactive compounds isolated from $A$. bisporus are promising for drugs against some deadly diseases. Therefore, an increasing trend in the use of $A$. bisporus has been observed due to its robust medicinal properties like anticancer, antioxidant, anti-diabetic, antimicrobial, and anti-obesity activity. Recently, tyrosinase and ergothioneine have been reported from this mushroom, making this mushroom more worth considering for nutritional and medicinal purposes. However, there is room for researchers to explore the cosmeceutical properties of this mushroom. In addition, more data are required to evaluate and confirm the exact mechanisms behind the treatment of specific diseases and to discover some novel drugs in this regard.

Author Contributions: Writing—original draft preparation, M.U. and G.M.; writing—review and editing, A.D.; supervision, A.D. All authors have read and agreed to the published version of the manuscript.

Funding: This research received no external funding.

Institutional Review Board Statement: Not applicable.

Informed Consent Statement: Not applicable.

Acknowledgments: The authors are thankful to Muhammad Ehsan, (visiting faculty of English literature at the University of Narowal, Narowal) for helping in improving the grammar.

Conflicts of Interest: The authors declare no conflict of interest.

\section{References}

1. Rosmiza, M.Z.; Davies, W.P.; Rosniza, A.C.R.; Jabil, M.J.; Mazdi, M. Prospects for Increasing Commercial Mushroom Production in Malaysia: Challenges and Opportunities. Mediterr. J. Soc. Sci. 2016, 7, 406-415. [CrossRef]

2. Raut, J.K. Current Status, Challenges and Prospects of Mushroom Industry in Nepal. Int. J. Agric. Econ. $2019,4,154$.

3. Bhushan, A.; Kulshreshtha, M. The medicinal Mushroom Agaricus bisporus: Review of phytopharmacology and potential role in the treatment of various diseases. J. Nature Sci. Med. 2018, 1, 4.

4. Grimm, D.; Wosten, H.A. Mushroom cultivation in the circular economy. Appl. Microbiol. Biotechnol. 2018, 102, 7795-7803. [CrossRef] [PubMed]

5. Nagy, M.; Socaci, S.; Tofană, M.; Biris-Dorhoi, E.S.; Țibulcă, D.; Salanță, L.; Petruț, G. Chemical Composition and Bioactive Compounds of Some Wild Edible Mushrooms. Bull. UASVM Food Sci. Technol. 2017, 74, 1. [CrossRef]

6. Fogarasi, M.; Socaci, S.A.; Dulf, F.V.; Diaconeasa, Z.M.; Fărcaș, A.C.; Tofană, M.; Semeniuc, C.A. Bioactive Compounds and Volatile Profiles of Five Transylvanian Wild Edible Mushrooms. Molecules 2018, 23, 3272. [CrossRef] 
7. Manzi, P.; Aguzzi, A.; Pizzoferrato, L. Nutritional value of mushrooms widely consumed in Italy. Food Chem. 2001, 73, 321-325. [CrossRef]

8. Shbeeb, D.A.; Farahat, M.F.; Ismail, H.M. Macronutrients analysis of fresh and canned Agaricus bisporus and Pleurotus ostreatus mushroom species sold in Alexandria markets, Egypt. Prog. Nutr. 2019, 21, 203-209.

9. Qing, Z.; Cheng, J.; Wang, X.; Tang, D.; Liu, X.; Zhu, M. The effects of four edible mushrooms (Volvariella volvacea, Hypsizygus marmoreus, Pleurotus ostreatus and Agaricus bisporus) on physicochemical properties of beef paste. LWT 2021, 135, 110063. [CrossRef]

10. Chikthimmah, N. Microbial Ecology of Mushroom Casing Soils and Preharvest Strategies to Enhance Safety and Quality of Fresh Mushrooms. Ph.D. Thesis, The Pennsylvania State University, State College, PA, USA, 2009; p. 98.

11. Zhang, M.Z.; Li, G.J.; Dai, R.C.; Xi, Y.L.; Wei, S.L.; Zhao, R.L. The edible wide mushrooms of Agaricus section Bivelares from Western China. Mycosphere 2017, 8, 1640-1652. [CrossRef]

12. Wasser, S.P.; Akavia, E. Regulatory Issues of Mushrooms as Functional Foods and Dietary Supplements: Safety and Efficacy. Mushrooms as Functional Foods; Wiley: New York, NY, USA, 2008; pp. 199-221.

13. Chang, S.T. Witnessing the development of the mushroom industry in China. Acta Edulis Fungi 2005, 12, 3-19.

14. Khan, A.A.; Gani, A.; Shah, A.; Masoodi, F.A.; Hussain, P.R.; Wani, I.A.; Khanday, F.A. Effect of $\gamma$-irradiation on structural, functional and antioxidant properties of $\beta$-glucan extracted from button mushroom (Agaricus bisporus). Innov. Food Sci. Emerg. Technol. 2015, 31, 123-130. [CrossRef]

15. Ruthes, A.C.; Rattmann, Y.D.; Malquevicz-Paiva, S.M.; Carbonero, E.R.; Cordova, M.M.; Baggio, C.H.; Santos, A.R.; Gorin, P.A.; Iacomini, M. Agaricus bisporus fucogalactan: Structural characterization and pharmacological approaches. Carbohydr. Polym. 2013, 92, 184-191. [CrossRef] [PubMed]

16. XuJie, H.; Na, Z.; SuYing, X.; ShuGang, L.; BaoQiu, Y. Extraction of BaChu mushroom polysaccharides and preparation of a compound beverage. Carbohydr. Polym. 2008, 73, 289-294. [CrossRef]

17. Chang, S.T.; Wasser, S.P. The role of culinary-medicinal mushrooms on human welfare with a pyramid model for human health Int. J. Med. Mushrooms 2012, 14, 95-134. [CrossRef]

18. Teichmann, A.; Dutta, P.C.; Staffas, A.; Jagerstad, M. Sterol and vitamin D2 concentrations in cultivated and wild grown mushrooms: Effects of UV irradiation. LWT 2007, 40, 815-822. [CrossRef]

19. Barros, L.; Cruz, T.; Baptista, P.; Estevinho, L.M.; Ferreira, I.C.F.R. Wild and commercial mushrooms as source of nutrients and nutraceuticals. Food Chem. Toxicol. 2008, 46, 2743-2747. [CrossRef]

20. Guillamon, E.; Garcia-Lafuente, A.; Lozano, M.; Rostagno, M.A.; Villares, A.; Martinez, J.A. Edible mushrooms: Role in the prevention of cardiovascular diseases. Fitoterapia 2010, 81, 715-723. [CrossRef] [PubMed]

21. Shao, S.; Hernandez, M.; Kramer, J.K.; Rinker, D.L.; Tsao, R. Ergosterol profiles, fatty acid composition, and antioxidant activities of button mushrooms as affected by tissue part and developmental stage. J. Agric. Food Chem. 2010, 58, 11616-11625. [CrossRef]

22. Muszynska, B.; Sułkowska-Ziaja, K.; Ekiert, H. Indole compounds in fruiting bodies of some edible Basidiomycota species. Food Chem. 2011, 125, 1306-1308. [CrossRef]

23. Reis, F.S.; Martins, A.; Barros, L.; Ferreira, I.C. Antioxidant properties and phenolic profile of the most widely appreciated cultivated mushrooms: A comparative study between in vivo and in vitro. Food Chem. Toxicol. 2012, 50, 1201-1207. [CrossRef] [PubMed]

24. Muslat, M.M.; Al-Assaffii, I.A.A.; Owaid, M.N. Agaricus bisporus product development by using local substrate with bioamendment. Int. J. Environ. Global Climate 2014, 2, 176-188.

25. Ahlavat, O.P.; Manikandan, K.; Singh, M. Proximate composition of different mushroom varieties and effect of UV light, exposure on vitamin D content in Agaricus bisporus and Volvariella volvacea. Mushroom Res. 2016, 25, 1-8.

26. Correa, R.C.G.; Brugnari, T.; Bracht, A.; Peralta, R.M.; Ferreira, I.C. Pleurotus spp. (oyster mushroom) related with its chemical composition: A review on the past decade findings. Trends Food Sci. Technol. 2016, 50, 103-117. [CrossRef]

27. El Sebaaly, Z.; Assadi, F.; Sassine, Y.N.; Shaban, N. Substrate types effect on nutritional composition of button mushroom (Agaricus bisporus). Agriculture Forestry 2019, 65, 73-80. [CrossRef]

28. Bernas, E.; Jaworska, G.; Lisiewska, Z. Edible mushrooms as a source of valuable nutritive constituents. Acta Sci. Pol. Technol. Alimen. 2006, 5, 5-20.

29. Pei, F.; Shi, Y.; Gao, X.; Wu, F.; Mariga, A.M.; Yang, W.; Zhao, L.; An, X.; Xin, Z.; Yang, F.; et al. Changes in non-volatile taste components of button mushroom (Agaricus bisporus) during different stages of freeze drying and freeze drying combined with microwave vacuum drying. Food Chem. 2014, 165, 547-554. [CrossRef]

30. Muszynska, B.; Kala, K.; Rojowski, J.; Grzywacz, A.; Opoka, W. Composition and Biological Properties of Agaricus bisporus Fruiting Bodies-a Review. Pol. J. Food Nutr. Sci. 2017, 67, 173-181. [CrossRef]

31. Ozturk, M.; Duru, M.E.; Kivrak, S.; Mercan-Dogan, N.; Turkoglu, A.; Ozler, M.A. In vitro antioxidant, anticholinesterase and antimicrobial activity studies on three Agaricus species with fatty acid compositions and iron contents: A comparative study on the three most edible mushrooms. Food Chem. Toxicol. 2011, 49, 1353-1360. [CrossRef]

32. Gheibi, N.; Saboury, A.A.; Haghbeen, K.; Moosavi-Movahedi, A.A. The effect of some osmolytes on the activity and stability of mushroom tyrosinase. J. Biosci. 2006, 31, 355-362. [CrossRef]

33. Tsai, S.Y.; Wu, T.P.; Huang, S.J.; Mau, J.L. Antioxidant properties of ethanolic extracts from culinary-medicinal button mushroom Agaricus bisporus (J. Lange) Imbach (Agaricomycetes) harvested at different stages of maturity. Int. J. Med. Mushrooms 2008, 10, 127-137. [CrossRef] 
34. Kalbarczyk, J.; Radzki, W. Cultivated mushrooms as a valuable diet constituent and a source of biologically active substances. Herba Pol. 2009, 55, 224-232.

35. Czapski, J. Antioxidant activity and phenolic content in some strains of mushrooms (Agaricus bisporus). Veg. Crops Res. Bull. 2004, $62,165-173$.

36. Labus, K.; Turek, A.; Liesiene, J.; Bryjak, J. Efficient Agaricus bisporus tyrosinase immobilization on cellulose-based carriers. Biochem. Eng. J. 2011, 56, 232-240. [CrossRef]

37. Heleno, S.A.; Diz, P.; Prieto, M.A.; Barros, L.; Rodrigues, A.; Barreiro, M.F.; Ferreira, I.C. Optimization of ultrasound-assisted extraction to obtain mycosterols from Agaricus bisporus L. by response surface methodology and comparison with conventional Soxhlet extraction. Food Chem. 2016, 197, 1054-1063. [CrossRef]

38. Muszynska, B.; Sułkowska-Ziaja, K.; Wojcik, A. Levels of physiologically active indole derivatives in the fruiting bodies of some edible mushrooms (Basidiomycota) before and after thermal processing. Mycosciene 2013, 54, 321-326. [CrossRef]

39. Gothwal, R.; Gupta, A.; Kumar, A.; Sharma, S.; Alappat, B.J. Feasibility of dairy waste water (DWW) and distillery spent wash (DSW) effluents in increasing the yield potential of Pleurotus flabellatus (PF 1832) and Pleurotus sajorcaju (PS 1610) on bagasse. Biotechnology 2012, 2, 249-257.

40. Cardoso, R.V.C.; Fernandes, A.; Barreira, J.C.M.; Verde, S.C.; Antonio, A.L.; Gonzalez-Paramas, A.M.; Barros, L.; Ferreira, I.C.F.R. Effectiveness of gamma and electron beam irradiation as preserving technologies of fresh Agaricus bisporus portobello: A comparative study. Food Chem. 2019, 278, 760-766. [CrossRef]

41. Hammond, J.B.W. Changes in composition of harvested mushrooms (Agaricus bisporus). Phytochemistry 1979, 18, 415-418. [CrossRef]

42. Burton, K.S. The effects of pre- and post-harvest development on Agaricus bisporus proteases. J. Hort. Sci. 1988, 63, 103-108. [CrossRef]

43. Braaksma, A.; Schaap, D.J. Protein analysis of the common mushroom Agaricus bisporus. Postharvest Biol. Technol. 1996, 7, 119-127. [CrossRef]

44. Sadiq, S.; Bhatti, H.N.; Hanif, M.A. Studies on chemical composition and nutritive evaluation of wild edible mushrooms. Iran J. Chem. Chem. Eng. 2008, 27, 151-154.

45. Mohiuddin, K.M.; Alam, M.; Arefin, T.; Ahmed, I. Assessment of nutritional composition and heavy metal content in some edible mushroom varieties collected from different areas of Bangladesh. Asian J. Med. Biol. Res. 2015, 1, 495-501. [CrossRef]

46. Citores, L.; Ragucci, S.; Ferreras, J.M.; Di Maro, A.; Iglesias, R. Ageritin, a Ribotoxin from Poplar Mushroom (Agrocybe aegerita) with Defensive and Antiproliferative Activities. ACS Chem. Biol. 2019, 14, 1319-1327. [CrossRef] [PubMed]

47. Fogarasi, M.; Diaconeasa, Z.M.; Pop, C.R.; Fogarasi, S.; Semeniuc, C.A.; Fărcaş, A.C.; Tibulcă, D.; Sălăgean, C.-D.; Tofană, M.; Socaci, S.A. Elemental Composition, Antioxidant and Antibacterial Properties of Some Wild Edible Mushrooms from Romania. Agronomy 2020, 10, 1972. [CrossRef]

48. Baars, J.J.P.; Sonnenberg, A.S.M.; Mumm, R.; Stijger, I.; Wehrens, R. Metabolites Contributing to Taste in Agaricus Bisporus; the foundation Stichting Dienst Landbouwkundig Onderzoek; PPO/PRI Report 1.19; Research Institute Praktijkonderzoek Plant \& Omgeving/Plant Research International, UR (University \& Research Centre): Wageningen, The Netherlands, 2016.

49. Hossain, M.S.; Alam, N.; Amin, S.M.R.; Basunia, M.A.; Rahman, A. Essential fatty acids contents of Pleurotus ostreatus, Ganoderma lucidum and Agaricus bisporus. Bangladesh J. Mushroom 2007, 1, 1-7.

50. Cheung, P.C.K. The nutritional and health benefits of mushrooms. Nutr. Bull. 2010, 35, 292-299. [CrossRef]

51. Tsai, S.Y.; Wu, T.P.; Huang, S.J.; Mau, J.L. Nonvolatile taste components of Agaricus bisporus harvested at different stages of maturity. Food Chem. 2007, 103, 1457-1464. [CrossRef]

52. Owaid, M.N.; Barish, A.; Shariati, M.A. Cultivation of Agaricus bisporus (button mushroom) and its usages in the biosynthesis of nanoparticles. Open Agric. 2017, 2, 537-543. [CrossRef]

53. Atila, F.; Owaid, M.N.; Shariati, M.A. The nutritional and medical benefits of Agaricus bisporus: A review. J. Microbiol. Biotechnol. Food Sci. 2017, 7, 281. [CrossRef]

54. Vetter, J. Chitin content of cultivated mushrooms Agaricus bisporus, Pleurotus ostreatus and Lentinula edodes. Food Chem. 2007, 102, 6-9. [CrossRef]

55. Cherno, N.; Osalina, S.; Nikitina, A. Chemical composition of Agaricus bisporus and Pleurotus ostreatus fruiting bodies and their morphological parts. Food Environ. Safe. 2013, 7, 291-299.

56. Falandysz, J.; Borovicka, J. Macro and trace mineral constituents and radionuclides in mushrooms: Health benefits and risk. Appl. Microbiol. Biotechnol. 2013, 97, 477-501. [CrossRef] [PubMed]

57. Caglarırmak, N. Determination of nutrients and volatile constituents of Agaricus bisporus (brown) at different stages. J. Sci. Food Agric. 2009, 89, 634-638. [CrossRef]

58. Lu, J.; Holmgren, A. Selenoproteins. J. Biol. Chem. 2009, 284, 723-727. [CrossRef]

59. Bernas, E.; Jaworska, G. Vitamins profile as an indicator of the quality of frozen Agaricus bisporus mushrooms. J. Food Compos. Anal. 2016, 49, 1-8. [CrossRef]

60. Furlani, R.P.Z.; Godoy, H.T. Vitamins B1 and B2 contents in cultivated mushrooms. Food Chem. 2008, 106, 816-819. [CrossRef]

61. Simon, R.R.; Phillips, K.M.; Horst, R.L.; Munro, I.C. Vitamin D mushrooms: Comparison of the composition of button mushrooms (Agaricus bisporus) treated post-harvest with UVB light or sunlight. J. Agric. Food Chem. 2011, 59, 8724-8732. [CrossRef] [PubMed] 
62. Roberts, J.S.; Teichert, A.; McHugh, T.H. Vitamin D2 formation from post-harvest UV-B treatment of mushrooms (Agaricus bisporus) and retention during storage. J. Agric. Food Chem. 2008, 56, 4541-4544. [CrossRef]

63. Das, B.; De, B.; Chetree, R.; Mandal, S.C. Medicinal aspect of mushrooms: A view point. In Herbal Medicine in India; Springer: Berlin/Heidelberg, Germany, 2020; Volume 5, pp. 509-532.

64. Dhamodharan, G.; Mirunalini, S. A Novel Medicinal Characterization of Agaricus bisporus (white button mushroom). Pharmacol. Online 2010, 2, 456-463.

65. Volman, J.J.; Mensink, R.P.; Van Griensven, L.J.L.D.; Plat, J. Effects of $\alpha$-glucans from Agaricus bisporus on ex vivo cytokine production by LPS and PHA-stimulated PBMCs; a placebo-controlled study in slightly hypercholesterolemic subjects. Eur. J. Clinic. Nutr. 2010, 64, 720-726. [CrossRef] [PubMed]

66. Adams, L.S.; Phung, S.P.; Wu, X.; Ki, L.; Chen, S. White button mushroom (Agaricus bisporus) exhibits antiproliferative and proapoptotic properties and inhibits prostate tumor growth in athymic mice. Nutr. Cancer 2008, 60, 744-756. [CrossRef]

67. Novaes, M.R.C.G.; Fabiana, V.M.C.R.; Goncalves, D.R.; Menezes, M.C. The effects of dietary supplementation with Agaricales mushrooms and other medicinal fungi on breast cancer: Evidence-based medicine. Clinics 2011, 66, 2133-2139. [CrossRef]

68. Jeong, S.C.; Koyyalamudi, S.R.; Jeong, Y.T.; Song, C.H.; Pang, G. Macrophage immunomodulating and anti-tumor activities of polysaccharides isolated from Agaricus bisporus white button mushrooms. J. Med. Food 2012, 15, 58-65. [CrossRef] [PubMed]

69. Khan, Z.U.; Aisikaer, G.; Khan, R.U.; Bu, J.; Jiang, Z.; Ni, Z.; Ying, T. Effects of composite chemical pretreatment on maintaining quality in button mushrooms (Agaricus bisporus) during post-harvest storage. Postharvest Biol. Technol. 2014, 95, 36-41. [CrossRef]

70. Oms-Oliu, G.; Aguilo-Aguayo, I.; Martin-Belloso, O.; Soliva-Fortuny, R. Effects of pulsed light treatments on quality and antioxidant properties of fresh-cut mushrooms (Agaricus bisporus). Postharvest Biol. Technol. 2010, 56, 216-222. [CrossRef]

71. Liu, J.; Jia, L.; Kan, J.; Jin, C.H. In vitro and in vivo antioxidant activity of ethanolic extract of white button mushroom (Agaricus bisporus). Food Chem. Toxicol. 2013, 51, 310-316. [CrossRef]

72. Yu, L.; Fernig, D.G.; Smith, J.A.; Milton, J.D.; Rhodes, J.M. Reversible inhibition of proliferation of epithelial cell lines by Agaricus bisporus (edible mushroom) lectin. Cancer Res. 1993, 53, 4627-46232. [PubMed]

73. Talpur, N.A.; Echard, B.W.; Fan, A.Y.; Jaffari, O.; Bagchi, D.; Preuss, H.G. Antihypertensive and metabolic effects of whole Maitake mushroom powder and its fractions in two rat strains. Mol. Cell. Biochem. 2002, 237, 129-136. [CrossRef]

74. Estruch, R.; Martinez-Gonzalez, M.A.; Corella, D.; Basora-Gallisa, J.; Ruiz-Gutierrez, V.; Covas, M.I.; Fiol, M.; Gómez-Gracia, E.; López-Sabater, M.C.; Escoda, R.; et al. Predimed Study Investigators. Effects of dietary fibre intake on risk factors for cardiovascular disease in subjects at high risk. J. Epidemiol. Community Health 2009, 63, 582-588. [CrossRef]

75. Jeong, S.C.; Jeong, Y.T.; Yang, B.K.; Islam, R.; Koyyalamudi, S.R.; Pang, G.; Cho, K.Y.; Song, C.H. White button mushroom (Agaricus bisporus) lowers blood glucose and cholesterol levels in diabetic and hypercholesterolemic rats. Nutr. Res. 2010, 30, 49-56. [CrossRef]

76. Calvo, M.S.; Mehrotra, A.; Beelman, R.B.; Nadkarni, G.; Wang, L.; Cai, W.; Goh, B.C.; Kalaras, M.D.; Uribarri, J. A retrospective study in adults with metabolic syndrome: Diabetic risk factor response to daily consumption of Agaricus bisporus (white button mushrooms). Plant Foods Human Nutr. 2016, 71, 245-251. [CrossRef] [PubMed]

77. Zaid, O.A.A.; Sonbaty, S.E.; Neama, M.A. Anti-diabetic activity of Agaricus bisporus: A biochemical and pathological study. Int. J. Pharma Sci. 2017, 7, 1740-1745.

78. Ramirez-Anguiano, A.C.; Santoyo, S.; Reglero, G.; Soler-Rivas, C. Radical scavenging activities, endogenous oxidative enzymes and total phenols in edible mushrooms commonly consumed in Europe. J. Sci. Food Agric. 2007, 87, 2272-2278. [CrossRef]

79. Savoie, J.M.; Minvielle, N.; Largeteau, M.L. Radical-scavenging properties of extracts from the white button mushroom, Agaricus bisporus. J. Sci. Food Agric. 2008, 88, 970-975. [CrossRef]

80. Jaworska, G.; Pogon, K.; Bernas, E.; Duda-Chodak, A. Nutraceuticals and Antioxidant Activity of Prepared for Consumption Commercial Mushrooms Agaricus bisporus and Pleurotus ostreatus. J. Food Qual. 2015, 38, 111-122. [CrossRef]

81. Gasecka, M.; Magdziak, Z.; Siwulski, M.; Mleczek, M. Profile of phenolic and organic acids, antioxidant properties and ergosterol content in cultivated and wild-growing species of Agaricus. Eur. Food Res. Technol. 2018, 244, 259-268. [CrossRef]

82. Sarikaya, S.B.O.; Gulcin, I. Radical scavenging and antioxidant capacity of serotonin. Curr. Bioact. Compd. 2013, 9, 143-152. [CrossRef]

83. Quchi, Y.; Yoshikawa, E.; Futatsubashi, M.; Yagi, S.; Ueki, T.; Nakamura, K. Altered brain serotonin transporter and associated glucose metabolism in Alzheimer disease. J. Nucl. Med. 2009, 50, 1260-1266.

84. Kothari, D.; Patel, S.; Kim, S.K. Anticancer and other therapeutic relevance of mushroom polysaccharides: A holistic appraisal. Biomed. Pharmacother. 2018, 105, 377-394. [CrossRef]

85. Chaitanya, M.V.N.L.; Jose, A.; Ramalingam, P.; Mandal, S.C.; Kumar, P.N. Multi-targeting cytotoxic drug leads from mushrooms. Asian Pacific J. Trop. Med. 2019, 12, 531. [CrossRef]

86. Zhang, J.J.; Ma, Z.; Zheng, L.; Zhai, G.Y.; Wang, L.Q.; Jia, M.; Jia, L. Purification and antioxidant activities of intracellular zinc polysaccharides from Pleurotus cornucopiae SS-03. Carbohydr. Polym. 2014, 111, 947-954. [CrossRef]

87. Smiderle, F.R.; Alquini, G.; Tadra-Sfeir, M.Z.; Iacomini, M.; Wichers, H.J.; Van Griensven, L.J. Agaricus bisporus and Agaricus brasiliensis $(1 \rightarrow 6)$ - $\beta$-d-glucans show immunostimulatory activity on human THP-1 derived macrophages. Carbohydr. Polym. 2013, 94, 91-99. [CrossRef] [PubMed]

88. McCleary, B.V.; Draga, A. Measurement of $\beta$-glucan in mushrooms and mycelial products. J. AOAC Int. 2016, 99, 364-373. [CrossRef] [PubMed] 
89. Jagadish, L.K.; Krishnan, V.V.; Shenbhagaraman, R.; Kaviyarasan, V. Comparative study on the antioxidant, anticancer and antimicrobial property of Agaricus bisporus (J.E. Lange) Imbach. before and after boiling. Afr. J. Biotechnol. 2009, 8, 654-661.

90. Heleno, S.A.; Martins, A.; Queiroz, M.J.R.; Ferreira, I.C. Bioactivity of phenolic acids: Metabolites versus parent compounds: A review. Food Chem. 2015, 173, 501-513. [CrossRef]

91. Hassan, M.A.A.; Rouf, R.; Tiralongo, E.; May, T.W.; Tiralongo, J. Mushroom lectins: Specificity, structure and bioactivity relevant to human disease. Int. J. Mol. Sci. 2015, 16, 7802-7838. [CrossRef] [PubMed]

92. Singh, S.; Lal, A.A.; Simon, S.; Ramteke, P.W. Efficacy of selected botanicals on biochemical constituents of white button mushroom Agaricus bisporus (Lange) Imbach. J. Pharmacogn. Phytochem. 2017, 6, 2070-2076.

93. Golak-Siwulska, I.; Kałuzewicz, A.; Wdowienko, S.; Dawidowicz, L.; Sobieralski, K. Nutritional value and health-promoting properties of Agaricus bisporus (Lange) Imbach. Herba Pol. 2018, 64, 71-81. [CrossRef]

94. Clark, L.C.; Combs, G.F.; Turnbull, B.W.; Slate, E.H.; Chalker, D.K.; Chow, J.; Krongrad, A. Effects of selenium supplementation for cancer prevention in patients with carcinoma of the skin: A randomized controlled trial. JAMA 1996, 276, 1957-1963. [CrossRef]

95. Spolar, M.R.; Schaffer, E.M.; Beelman, R.B.; Milner, J.A. Selenium-enriched Agaricus bisporus mushrooms suppress 7, 12dimethlybenz [a] anthracene bioactivation in mammary tissue. Cancer Lett. 1999, 138, 145-150. [CrossRef]

96. Rzymski, P.; Mleczek, M.; Niedzielski, P.; Siwulski, M.; Gasecka, M. Cultivation of Agaricus bisporus enriched with selenium, zinc and copper. J. Sci. Food Agric. 2017, 97, 923-928. [CrossRef] [PubMed]

97. Kim, D.H.; Yang, B.K.; Jeong, S.C.; Park, J.B.; Cho, S.P.; Das, S.; Yun, J.W.; Song, C.H. Production of a hypoglycemic extracellular polysaccharide from the submerged culture of the mushroom, Phellinus linteus. Biotechnol. Lett. 2001, 23, 513-517. [CrossRef]

98. Huang, C.; Lii, C.; Lin, A.; Yeh, Y.; Yao, H.; Li, C.; Wang, T. Protection by Chrysin, Apigenin, and Luteolin against oxidative stress is mediated by The Nrf2-Dependent Up-Regulation of Heme Oxygenase 1 and Glutamate Cysteine Ligase in Rat Primary Hepatocytes. Arch. Toxicol. 2013, 87, 167-178. [CrossRef] [PubMed]

99. Leyva-Lopez, N.; Gutierrez-Grijalva, E.P.; Vazquez, O.G.; Heredia, J.B. Essential Oils of Oregano: Biological Activity beyond Their Antimicrobial Properties. Molecules 2017, 22, 1-24.

100. Ekowati, N.; Yuniati, N.I.; Hernayanti, H.; Ratnaningtyas, N.I. Anti-diabetic Potentials of Button Mushroom (Agaricus bisporus) on Alloxan-Induced Diabetic Rats. Biosaintifika J. Biol. Biol. Edu. 2018, 10, 655-662. [CrossRef]

101. Cheung, P.C.K. Dietary fiber content and composition of some cultivated edible mushroom fruiting bodies and mycelia. J. Agric. Food Chem. 1996, 44, 468-471. [CrossRef]

102. Yamashita, K.; Kawai, K.; Itakura, M. Effect of fructo oligosaccharides on blood glucose and serum lipids in diabetic subjects. Nutr. Res. 1984, 4, 961-966. [CrossRef]

103. Todesco, T.; Rao, A.V.; Bosello, O. Propionate lowers blood glucose and alters lipid metabolism in healthy subjects. Am. J. Clinic. Nutr. 1991, 54, 860-865. [CrossRef]

104. Wong, J.M.; de Souza, R.; Kendall, C.W.; Emam, A.; Jenkins, D.J. Colonic health: Fermentation and short chain fatty acids. J. Clin. Gastroenterol. 2006, 40, 235-243. [CrossRef] [PubMed]

105. Esmaillzadeh, A.; Azatbakth, L. Food intake patterns may explain the high prevalence of cardiovascular risk factors among Iranian women. J. Nutr. Nutrit. Epidemiol. 2008, 138, 1469-1475. [CrossRef] [PubMed]

106. Lin, X.; Ma, L.; Racette, S.B.; Spearie, C.L.A.; Ostlund, R.E. Phytosterol glycosides reduce cholesterol absorption in humans. American journal of physiology. Gastrointest. Liver Physiol. 2009, 296, 931-935. [CrossRef] [PubMed]

107. Xu, H.; Yang, Y.J.; Yang, T.; Qian, H.Y. Statins and stem cell modulation. Ageing Res. Rev. 2013, 12, 1-7. [CrossRef]

108. Zepeda-Bastida, A.; Ojeda-Ramirez, D.; Soto-Simental, S.; Rivero-Perez, N.; Ayala-Martínez, M. Comparison of antibacterial activity of the spent substrate of Pleurotus ostreatus and Lentinula edodes. J. Agric. Sci. 2016, 8, 43-49. [CrossRef]

109. Mattila, P.; Konko, K.; Eurola, M.; Pihlava, J.M.; Astola, J.; Vahteristo, L.; Hietaniemi, V.; Kumpulainen, J.; Valtonen, M.; Piironen, V. Contents of vitamins, mineral elements, and some phenolic compounds in cultivated mushrooms. J. Agric. Food Chem. 2001, 49, 2343-2348. [CrossRef] [PubMed]

110. De Silva, D.D.; Rapior, S.; Hyde, K.D.; Bahkali, A.H. Medicinal mushrooms in prevention and control of diabetes mellitus. Fungal Divers. 2012, 56, 1-29. [CrossRef]

111. Parashare, V.; Pal, S.; Bhandari, A. Antimicrobial and nutritional studies on Agaricus bisporus and Pleurotus ostreatus. Acta Boil. Indica 2013, 2, 310-315.

112. Badalyan, S.M. The main groups of therapeutic compounds of medicinal mushrooms. Med. Mycol. 2001, 3, 16-23.

113. Choi, M.H.; Han, H.K.; Lee, Y.J.; Jo, H.G.; Shin, H.J. In vitro anticancer activity of hydrophobic fractions of Sparassis latifolia extract using AGS, A529, and HepG2 cell lines. J. Mushroom 2014, 12, 304-310. [CrossRef]

114. Lee, B.; Park, J.; Park, J.; Shin, H.J.; Kwon, S.; Yeom, M.; Sur, B.; Kim, S.; Kim, M.; Lee, H.; et al. Cordyceps militaris improves neurite outgrowth in Neuro2a cells and reverses memory impairment in rats. Food Sci. Biotechnol. 2011, 20, 1599-1608. [CrossRef]

115. Mortimer, P.E.; Karunarathna, S.C.; Li, Q.; Gui, H.; Yang, X.; Yang, X.; He, J.; Ye, L.; Guo, J.; Li, H. Prized edible Asian mushrooms: Ecology, conservation and sustainability. Fungal Divers. 2012, 56, 31-47. [CrossRef]

116. Shang, X.; Tan, Q.; Liu, R.; Yu, K.; Li, P.; Zhao, G.P. In vitro anti-Helicobacter pylori effects of medicinal mushroom extracts, with special emphasis on the Lion's Mane mushroom, Hericium erinaceus (higher basidiomycetes). Int. J. Med. Mushrooms 2013, 15, 165-174. [CrossRef]

117. Soltanian, H.; Rezaeian, S.H.; Shakeri, A.; Janpoor, J.; Pourianfar, H.R. Antibacterial activity of crude extracts and fractions from Iranian wild-grown and cultivated Agaricus spp. Biomed. Res. 2016, 27, 56-59. 
118. Tambekar, D.H.; Sonar, T.P.; Khodke, M.V.; Khante, B.S. The novel antibacterials from two edible mushrooms: Agaricus bisporus and Pleurotus sajorcaju. Int. J. Pharmacol. 2006, 2, 584-587.

119. Ozen, T.; Darcan, C.; Aktop, O.; Turkekul, I. Screening of antioxidant, antimicrobial activities and chemical contents of edible mushrooms wildly grown in the Black Sea region of Turkey. Comb. Chem. High Throughput Screen. 2011, 14, 72-84. [CrossRef]

120. Stojkovic, D.; Reis, F.S.; Glamoclija, J.; Ciric, A.; Barros, L.; Van Griensven, L.J.; Ferreira, I.C.; Sokovic, M. Cultivated strains of Agaricus bisporus and A. brasiliensis: Chemical characterization and evaluation of antioxidant and antimicrobial properties for the final healthy product-natural preservatives in yoghurt. Food Funct. 2014, 5, 1602-1612. [CrossRef]

121. Gebreyohannes, G.; Nyerere, A.; Bii, C.; Berhe Sbhatu, D. Determination of the antimicrobial activity of extracts of indigenous wild mushrooms against pathogenic organisms. Evid. Based Complement. Alternat. Med. 2019, 2019, 6212673. [CrossRef]

122. Tehrani, M.H.H.; Fakhrehoseini, E.; Nejad, M.K.; Mehregan, H.; Hakemi-Vala, M. Search for proteins in the liquid extract of edible mushroom, Agaricus bisporus, and studying their antibacterial effects. Iran. J. Pharmaceut. Res. 2012, 11, 145.

123. Risan, M.H.; Taemor, S.H.; Muhsin, A.H.; Hussan, S. Antibacterial activity of Agaricus bisporus and Pleurotus ostreatus extracts against some gram negative and positive bacteria. Eur. J. Biomed. 2017, 4, 9-15.

124. Delgado-Povedano, M.M.; Sanchez, D.M.V.; Bautista, J.; Priego-Capote, F.; Castro, M.D.L. Tentative identification of the composition of Agaricus bisporus aqueous enzymatic extracts with antiviral activity against HCV: A study by liquid chromatographytandem mass spectrometry in high resolution mode. J. Funct. Foods 2016, 24, 403-419. [CrossRef]

125. Ruthes, A.C.; Rattmann, Y.D.; Carbonero, E.R.; Gorin, P.A.J.; Iacomini, M. Structural characterization and protective effect against murine sepsis of fucogalactans from Agaricus bisporus and Lactarius rufus. Carbohydr. Polym. 2012, 87, 1620-1627. [CrossRef]

126. Komura, D.L.; Carbonero, E.R.; Gracher, A.H.P.; Baggio, C.H.; Freitas, C.S.; Marcon, R.; Santos, A.R.; Gorin, P.A.; Iacomini, M. Structure of Agaricus spp. fucogalactans and their anti-inflammatory and antinociceptive properties. Bioresour. Technol. 2010, 101, 6192-6199. [CrossRef] [PubMed]

127. Wu, Y.; Choi, M.H.; Li, J.; Yang, H.; Shin, H.J. Mushroom cosmetics: The present and future. Cosmetics 2016, 3, 22. [CrossRef]

128. Kamarudzaman, A.N.; Chay, T.C.; Amir, A.; Talib, S.A. Biosorption of Mn (II) ions from aqueous solution by Pleurotus spent mushroom compost in a fixed-bed column. Procedia Soc. Behav. Sci. 2015, 195, 2709-2716. [CrossRef]

129. Taofiq, O.; Heleno, S.A.; Calhelha, R.C.; Alves, M.J.; Barros, L.; Barreiro, M.F.; Gonzalez-Paramas, A.M.; Ferreira, I.C. Development of mushroom-based cosmeceutical formulations with anti-inflammatory, anti-tyrosinase, antioxidant, and antibacterial properties. Molecules 2016, 21, 1372. [CrossRef]

130. Kim, D.; Park, J.; Kim, J.; Han, C.; Yoon, J.; Kim, N.; Seo, J.; Lee, C. Flavonoids as mushroom tyrosinase inhibitors: A fluorescence quenching study. J. Agric. Food Chem. 2006, 54, 935-941. [CrossRef]

131. Chang, T.S. An updated review of tyrosinase inhibitors. Int. J. Mol. Sci. 2009, 10, 2440-2475. [CrossRef] [PubMed]

132. Lee, J.S.; Shin, D.B.; Lee, S.M.; Kim, S.H.; Lee, T.S.; Jung, D.C. Melanogenesis inhibitory and antioxidant activities of Phellinus baumii methanol extract. Korean J. Mycol. 2013, 41, 104-111. [CrossRef]

133. Taofiq, O.; Gonzalez-Paramas, A.M.; Martins, A.; Barreiro, M.F.; Ferreira, I.C.F.R. Mushrooms extracts and compounds in cosmetics, cosmeceuticals and nutricosmetics-A review. Ind. Crops Prod. 2016, 90, 38-48. [CrossRef]

134. Papakonstantinou, E.; Roth, M.; Karakiulakis, G. Hyaluronic acid: A key molecule in skin aging. Dermatoendocrinology 2012, 4, 253-258. [CrossRef]

135. Leem, K.H. Effects of Olibanum Extracts on Collagenase Activity and Procollagen Synthesis in Hs68 Human Fibroblasts and Tyrosinase Activity. Int. J. Biosci. Biotechnol. 2015, 7, 127-134.

136. Thring, T.S.; Hili, P.; Naughton, D.P. Anti-collagenase, anti-elastase and antioxidant activities of extracts from 21 plants. BMC Complemen. Altern. Med. 2009, 9, 27. [CrossRef] [PubMed]

137. Miyake, M.; Yamamoto, S.; Sano, O.; Fujii, M.; Kohno, K.; Ushio, S.; Iwaki, K.; Fukuda, S. Inhibitory effects of 2-amino-3H-phenoxazin3one on the melanogenesis of murine B16 melanoma cell line. Biosci. Biotechnol. Biochem. 2010, 74, 753-758. [CrossRef]

138. Martins, N.; Barros, L.; Henriques, M.; Silva, S.; Ferreira, I.C.F.R. In vivo anti-candida activity of phenolic extracts and compounds: Future perspectives focusing on effective clinical interventions. BioMed Res. Int. 2015, 247382, 1-14.

139. Alves, M.J.; Ferreira, I.C.; Martins, A.; Pintado, M. Antimicrobial activity of wild mushroom extracts against clinical isolates resistant to different antibiotics. J. Appl. Microbiol. 2012, 113, 466-475. [CrossRef] [PubMed]

140. Racz, L.; Bumbalova, A.; Harangozo, M.; Tolgyessy, J.; Tomecek, O. Determination of cesium and Selenium in cultivated mushrooms using radionuclide X-ray fluorescence technique. J. Radioanal. Nucl. Chem. 2000, 245, 611-614. [CrossRef]

141. Ogra, Y.; Ishiwata, K.; Encinar, J.R.; Łobinski, R.; Suzuki, K.T. Speciation of Selenium in selenium-enriched shiitake mushroom, Lentinula edodes. Anal. Bioanal. Chem. 2004, 379, 861-866. [CrossRef]

142. Jeong, Y.T.; Yang, B.K.; Jeong, S.C.; Kim, S.M.; Song, C.H. Ganoderma applanatum: A promising mushroom for anti-tumor and immunomodulating activity. Phytother. Res. 2008, 22, 614-619. [CrossRef] 